\title{
Influence Customer Meal Experience to Behavior Intention in Hotel Restaurant
}

\author{
Mulyati ${ }^{1}$, Prastiti Laras Nugraheni ${ }^{2}$, Nurlaila Abdullah Mashabi ${ }^{3}$ \\ \{imoel.mulyati@gmail.com\} \\ Education of Family Welfare, Universitas Negeri Jakarta, Indonesia ${ }^{123}$
}

\begin{abstract}
A good impression on the meal experience at a hotel restaurant is expected to affect customer satisfaction, give the hotel a good image, and encourage consumers to make repeat purchases at the hotel restaurant. This study aimed to determine the influence of customer meal experience on behavioral intention in the restaurant hotel in Jakarta. This study uses an explanatory approach involved which 100 respondents. Meal experience was measured using the FAMM Scale with three dimensions (product, room, atmosphere) and behavior intention measure with three dimensions (Loyalty to Company, Propensity to Switch, and Willingness to Pay More). Furthermore, the data were analyzed using descriptive analysis and inferential. The results showed that Customer meal experiences with Behavior intention have a strong relationship. The correlation coefficient value shows a positive value. It means that if the customer meal experience is getting better, behavior intention will also increase. The customer eating experience influenced behavioral intention by $29.6 \%$.
\end{abstract}

Keywords: Meal Experience; Behavior Intention; FAMM Scale

\section{Introduction}

The tourism industry is growing quite rapidly in Indonesia. Based on the Central Statistics Agency (2019), the number of foreign tourist visits from January to April 2019 reached 5.12 million visits. This number increased by 3.22 percent compared to 2018 during the same period. The more rapid development of tourism needs to balance with hotel rooms, restaurants, and other accommodations. Hotel is a business supporting tourism by providing accommodation for tourists (Pramadivara \& Seminari, 2014). The Regulation of the Minister of Tourism and Creative Economic of the Republic of Indonesia of 2013 concerning hotel business standards stated that hotels provide accommodation, rooms with daily food and beverage services, entertainment activities, and other facilities for profit.

The growing development of hospitality in Indonesia requires the hotel industry to increase customer satisfaction. Good products and excellent service are strategies in providing satisfaction to customers. Customer satisfaction is very important in business competition in the hotel world. Many hotel companies compete to improve their products and services to meet their guests'/customers' expectations and satisfaction. Kotler (2002) states that satisfaction is a person's feelings after comparing the performance or perceived results with expectations. One thing that can lead to consumer satisfaction when coming and eating at a restaurant is the eating experience felt by each customer (Meal experience). Meal experience is the result of the interaction between a consumer and elements in a restaurant from the 
consumer (Tandjojo \& Nugroho, 2009). The restaurant in a hotel is not the main product sold by the hotel. However, the hotel restaurant can be a determining factor for consumers in choosing a hotel.

Revenue from the sale of food and beverages at the hotel restaurant is the largest sector that maximizes hotel financial income. Therefore, hoteliers in the hotel industry should not rule out hotel restaurants. To compete with other hotels, businesspeople must prepare a strategy to provide satisfaction to their customers. One thing that can lead to consumer satisfaction when coming and eating at a restaurant is the eating experience felt by each customer (Meal experience). Customer satisfaction will create a good hotel image. Consumers satisfied with the goods and services they consume will tend to give a good image to the product or service and buy again from the same producer.

This research needs to determine customers' dining experience at a hotel and how it affects the hotel restaurant behavior intentions. The hope is that this research can improve the hotel restaurant's quality so that it can provide a memorable meal experience. A good impression on the meal experience at a hotel restaurant is expected to affect customer satisfaction, give the hotel a good image, and encourage consumers to make repeat purchases at the hotel restaurant. If this happens, it will further increase the hotel profit.

\section{Methodology}

This research uses a quantitative approach with an explanatory research type. The population in this study are people who have visited the restaurant in a hotel in Jakarta. The hotel restaurants used in this study are restaurants located in hotels that have national and international networks. A sample of 100 respondents was selected using a purposive sampling method because the respondent had eaten at a restaurant in a Jakarta hotel, and the respondents were at least 17 years old. The data collected in this study is primary data consisting of customer meal experience and behavioral intention. The research data was collected using google form. Subjects in this study have eaten in hotel restaurants and are at least 17 years old.

\section{Result and Discussion}

\section{Characteristic of Respondent}

Respondents in this study were 100 respondents. Research respondents based on gender, age, occupation, income, and type of hotel shown in the following table and figure.

Gender

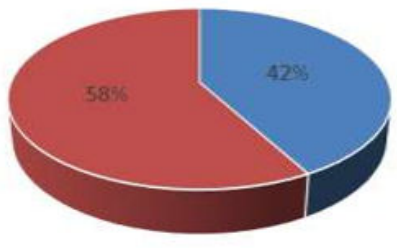

- Male = Female

Fig 1. Gender 


\section{Gender}

The respondents used consisted of female respondents were 58 people (58\%), and male respondents were 42 people (42\%). Respondent identity based on gender shown in picture 1 .

\section{Age of Respondents}

Respondents used in this study are people who have an age range 16 people aged 17-25 years (16\%), 29 people aged 26-35 years (29\%), 28 people aged 36-45 years (28\%), 16 respondents with age range $46-55$ years (16\%), ten respondents who have an age range of 5665 years $(10 \%)$.), and respondents with an age range of $>65$ are one person (1\%). Respondent identity based on age shown in Picture 2.

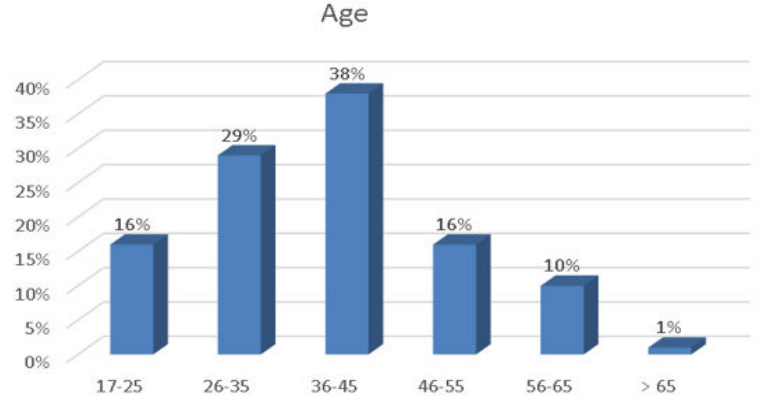

Profession

Fig 2. Age

Characteristics of respondents based on their profession, it is known that 4 people work as civil servants, 27 respondents are teachers (teachers/lecturers), 10 respondents are entrepreneurs, 28 respondents who work as employees' private sector, 9 respondents who work as students, 9 respondents who work as housewives, 1 respondent who is a freelance worker, and 2 respondents who work as a doctor. The characteristics of respondents based on their profession shown in Picture 3.

Profession

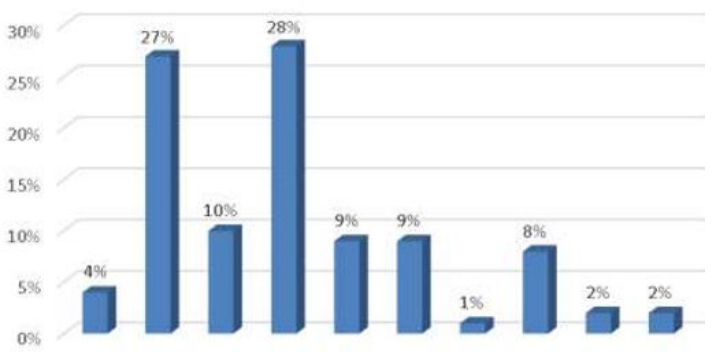

Fig 3. Profession

\section{Income}

Based on the results of this study, it is known that respondents who have an income of $<$ IDR $1,000,000$ are 15 people $(15 \%)$, respondents who have an income range of IDR $1,100,000$ - IDR 3,000,000 are 7 people (7\%), respondents who have an income range IDR $3,100,000$ - IDR $5,000,000$ as many as 24 people $(24 \%)$, respondents who have an income range of IDR 5,100,000 - IDR 7,000,000 are 7 people (7\%), respondents who have an income range of IDR 7,100,000 - IDR 10,000,000 as many as 23 people (23\%), and respondents who had an income> IDR 10,000,000 were 24 people (24\%). The identity of the respondents based on income shown in Picture 4. 


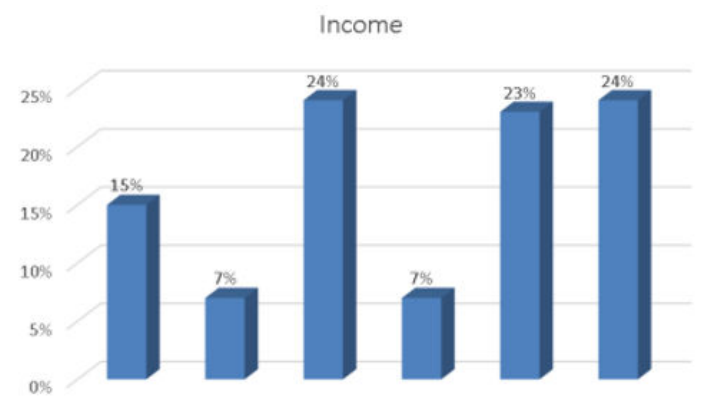

Fig 4. Income

\section{Type of Hotel}

Based on the data obtained, it is known that respondents who frequently visit 1-star hotels are 1 person $(1 \%)$, respondents who frequently visit 2 -star hotels are 1 person $(1 \%)$, respondents who frequently visit 3 -star hotels are 18 people $(18 \%)$, respondents who frequently visited 4 -star hotels were 53 people (53\%), and respondents who frequently visited 5 -star hotels were 27 people (27\%). The identity of the respondents by type of hotel shown in Picture 5.

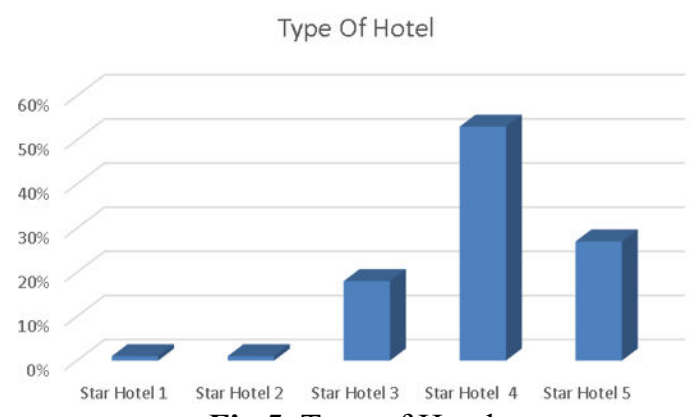

\section{Customer's Meal Experience}

Fig 5. Type of Hotel

Based on the research results, the variable meal experience for 100 hotel restaurants in Jakarta showed a percentage of $87.8 \%$ with an average value of 3.51 . The product dimension and the atmosphere dimension do not significantly differ, with the average value of the product dimensions of 3.52 and the atmosphere of 3.54. In contrast, room dimensions have a mean of 3.41. It shows that hotel restaurants in Jakarta have provided meal experiences to their visitors, but each dimension can still be improved, especially the room dimension.

The room dimension in the meal experience is one very important aspect, considering that the activities carried out by consumers occur in the room, such as consumer products. Indicators in the room dimensions in this study are design and decoration. Nowadays, a restaurant's design and decoration are very important because some urban people nowadays make eating out as part of the fun or as a solution to entertain relationships, guests, or family. Therefore, the restaurant business is growing and causing increased competition.

So, to attract customer interest, not only good food is needed but an attractive design and interior. Following Pile (2007), restaurant design aims to create an atmosphere and atmosphere to support the character of the food and services offered to create a memorable dining experience, to encourage customers to return and recommend restaurants to others. Besides, a comfortable and attractive restaurant will make consumers feel at home to linger so that it is possible to buy again, so there needs to be attentive to every restaurant's interior. Liu 
and Jang in Wardono (2011), using an extension of the Mehrabian and Russell model, proved that all elements of the interior environment in a restaurant, whether tangible or not, can significantly impact consumers' psychological response.

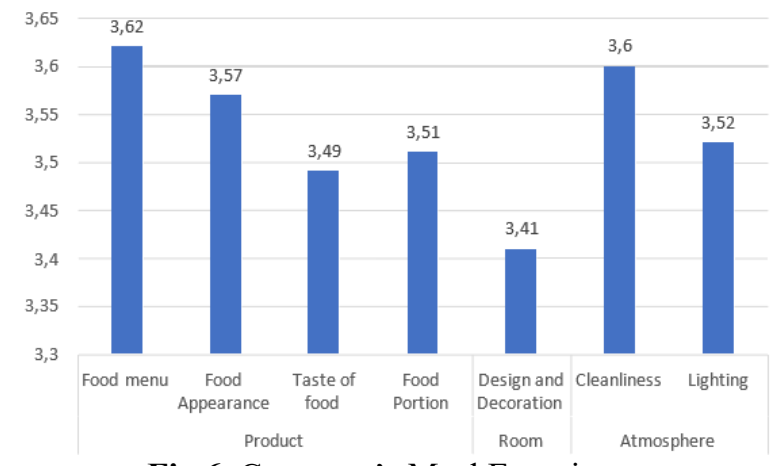

Fig 6. Customer's Meal Experience

There are indicators of the food menu, food appearance, food taste, and food portions in a hotel restaurant's product dimension. According to Gustafsson et al. (2006), the product of a restaurant includes the type of food and drink served the appearance of the food which is the moment of truth that decides whether a restaurant is successful or not in serving food, and the taste of food and drink itself, regardless of the taste of food and beverages. Is what determining whether or not the consumer's expectations are met. Based on the research results, it is known that the highest indicator is on the food menu, which is 3.62. The food menu at hotels usually has various menus, ranging from snacks, Indonesian food, western food, and various drinks choices.

Besides, hotel restaurants are usually also provided in a buffet system with a variety of menu choices. Customers can choose the desired menu as much as they like to create a satisfying dining experience for their visitors. The lowest indicators are taste and portion of food with an average value of 3.49 and 3.51. It shows that customers think that the taste and portion of food in the hotel is of fairly good quality but still needs improvement. Usually, for a proportion of meals (ala carte), hotel restaurants have a smaller portion than other restaurants. Kotler (2003), also states that product quality is the overall characteristics and characteristics of a product or service that affect its ability to satisfy stated or implied needs.

The atmosphere's dimension is an aspect that discusses how the condition of a room is both tangible and intangible. The indicators contained in this dimension concern cleanliness and lighting. According to Alonso (2010), the atmosphere, which consists of temperature, lighting, smells, and sounds, directly contributes to creating an experience. The study results show that the atmosphere of hotel restaurants in Indonesia is quite good, with a mean value of 3.6 and 3.52. With good cleanliness and lighting, guests can feel comfortable eating and chat at the hotel restaurant, thus creating a pleasant meal experience. According to Sweeney \& Wyber (2002), atmospheric describes an attempt to design a buying atmosphere to produce an emotional effect that increases the likelihood of buying. In other words, a restaurant atmosphere can be used to describe a place where guests can feel comfortable

\section{Behavioral Intention}

Creating behavioral intention from consumers becomes the main focus when customer satisfaction has been felt. At the initial purchase in a restaurant, consumers can feel both 
positive and negative impressions of the food quality, service quality, and physical environment that the restaurant has. After making a purchase, consumers can evaluate the results of the purchase. If consumers get satisfaction, it can create behavioral intentions. However, if the consumer is not satisfied, the consumer can decide to move to a competitor. Consumer satisfaction will create a good hotel image. Consumers satisfied with the goods and services they consume will tend to give a good image to the product or service and buy again from the same producer. Behavioral intention arises from this satisfaction because it is the desire to repeat good experiences and avoid bad experiences (Solomon, 2002).

Table 1. Behavioral Intention

\begin{tabular}{|c|c|c|c|}
\hline No & Item & Score & $\%$ \\
\hline 1. & Return to the hotel restaurant in the future & 341 & 3.41 \\
\hline 2. & $\begin{array}{l}\text { Recommended the hotel restaurant to my friends } \\
\text { or others. }\end{array}$ & & 3.31 \\
\hline 3. & Have a strong sense of Loyalty to the hotel restaurant & 303 & 3.03 \\
\hline 4. & $\begin{array}{l}\text { Choose a hotel restaurant service to order food } \\
\text { when staying at a hotel }\end{array}$ & 321 & 3.21 \\
\hline 5. & $\begin{array}{l}\text { To say positive things about the hotel restaurant were } \\
\text { I stayed }\end{array}$ & 338 & 3.38 \\
\hline & $\begin{array}{l}\text { Share the satisfaction I get at the hotel restaurant } \\
\text { where I stay with other potential customers }\end{array}$ & 325 & 3.25 \\
\hline & $\begin{array}{l}\text { Suggesting other potential guests to use the } \\
\text { in-house restaurant services to order food and } \\
\text { not to order food from outside }\end{array}$ & 311 & 3.11 \\
\hline 8. & Encourage others to visit the restaurant & 316 & 3.16 \\
\hline
\end{tabular}

The results showed that the behavioral intention variable of 100 hotel restaurant visitors showed that the dimensions of Loyalty to the company had an average value of $3.24(40.50 \%)$ and the Propensity to Switch dimension had an average of $3.22(40.22 \%)$ where the two dimensions did not show a significant difference. And the remaining $19.19 \%$ of other dimensions not examined in this study. This shows that consumers have the satisfaction of feeling a positive impression of the restaurant they visit, thus encouraging consumers to come back again and voluntarily recommend to friends and relatives.

Dimensions of Loyalty to Company This is when customers make repeat purchases, consumers cannot be influenced by competitors to move, and consumers are willing to recommend to others. When consumers feel their needs are met and feel satisfied, positive emotions will emerge to influence future consumer behavior, forming positive behavior. Consumers satisfied with the food, service, environment, and value obtained from the restaurants they visit will intend to behave well to be loyal. Besides, consumers will also be willing to pay more and are willing to provide input to build a restaurant (Khuana, 2016). 


\section{Influence Customer Meal Experience to Behavior Intention}

Meal experience is the key to customer satisfaction and restaurant benefits (Fraikue, 2014). Customer satisfaction is very valuable and maintains the existence of these customers to keep a business running. Customer satisfaction will create a good hotel image. Consumers satisfied with the goods and services they consume will tend to give a good image to the product or service and buy again from the same producer. Behavioral intention arises from this satisfaction because it is the desire to repeat good experiences and avoid bad experiences (Solomon, 2002). The results of this study indicate that meal experience has a strong relationship with behavioral intention. The correlation coefficient X3 and Y are $0.537 * *$. It means that the relationship strength (correlation) between the variable Customer meal experience and Behavior intention has a strong relationship strength, namely 0.537. The correlation coefficient value of 0.537 also shows a positive value, so it is unidirectional. It means that if the Customer meal experience is getting better, the Behavior intention will also increase.

This study shows that the $\mathrm{R}$ Square value is 0.296 , meaning that the Customer meal experience $(\mathrm{X})$ variable affects the behavior intention variable $(\mathrm{Y})$ by $29.6 \%$. It is in line with previous research, namely the research conducted by Liu and Jang (2009). It is a descriptive study that aims to examine Chinese restaurants' attributes that affect American customers' satisfaction and behavioral intention. They found that dining experience had a significant effect on behavioral intention. These findings are different from research conducted by Hutama and Subagio (2014), who found that dining experience has no significant behavioral intention. But dining experience has an indirect effect on behavioral intention through customer satisfaction. Namkung and Jang (2008); Liu and Jang (2009); Hutama and Subagio (2014); Canny (2014) found that dining experience has a significant effect on customer satisfaction.

\section{Conclusion}

This study shows that meal experience influences behavioral intention. This research can become the basis for developing meal experiences in hotel restaurants to improve hotel quality, win competitions in the hotel industry, and increase hotel profits.

\section{References}

[1] Alonso, A.D. \& O’Neill, M. (2010). Costumers' Ideal Eating Out Experience as It Refers to Restaurant Style: A Case Study. Journal of Retail \& Leisure Property, 9(4), pp. 263-276.

[2] Canny, I. U., (2014). Measuring The Mediating Role of Dining Experience Attributes on Customer Satisfaction and Its Impact on Behavioral Intentions Of Casual Dining Restaurant in Jakarta. International Journal of Innovation, Management and Technology, Vol. 5, No. 1, February 2014.

[3] Fraikue, Frances Betty. (2014). The Meal Experience Of Customers Of Grade 3 Restaurants In Sekondi- Takoradi. https://www.researchgate.net/publication/306562903

[4] Gustafsson, I.-B., Öström, Å., Johansson, J., \& Mossberg, L. (2006). The Five Aspects Meal Model: A Tool for Developing Meal Services In Restaurants. Journal of Foodservice, 17(2), 8493. Retrieved August 23, 2014, from http://download.interscience.wiley.com.ludwig.lub.lu.se

[5] Hutama, Christanto Leoma and Hartono Subagio. (2014).Analysis of the effect of dining experience on behavioral intention with customer satisfaction as an intervening variable (case 
study: domicile kitchen and lounge). Petra Marketing Management, vol. 2, no. 1

[6] Kotler, P. (2003). Marketing Management. New Jersey: Prentice Hall

[7] Khuana, Kevin. (2016). The Influence of Hedonic Value on Behavioural Intention with Customer Satisfaction as Intervening Variables (Case Study In: 1903 - Heritage Dining). Media Meneliti

[8] Liu, Y.H. and Jang, S. (2009). The effects of dining atmospherics: an extended MehrabianRussell model. International Journal of Hospitality Management, Vol. 28 No. 4, pp. 494-503.

[9] Namkung, Y., \& Jang, S. (2008). Does food quality really matter in restaurants? Its impact on customer satisfaction and behavioral intentions. Journal of Hospitality and Tourism Research, vol. 31(3), pp. 387-409

[10] Pile, J.F. (2007). Interior Design $4^{\text {th }}$ ed. New Jersey: Pearson Education, Inc.

[11] Solomon, R. Michael. (2002). Consumer Behavior, Buying, Having, and Being. 8th. Edition. New Jersey: Prentice Hall

[12] Sweeney, J.C. \& Wyber, F. (2002). The Role of Cognitions and Emotions in The Music approach avoidance Behaviour Relationship. Journal of Services Marketing 16:51-69

[13] Tandjojo, N., \& Nugroho, A. (2009). Analysis of the effect of meal experience on consumer loyalty of Japanese restaurants in Surabaya. [Doctoral dissertation]. Petra Christian University.

[14] Wardono, P. (2011). An Exploration of Interior Environmental Cues as Predictor Of Social Dining Behavior Of Young Indonesians. Japan: Chiba.

[15] Zeithaml, a, Berry, L., \& Parasuraman, A. (1996). Behavioral Consequences of Service Quality.Journal of Marketing, 60(2), 31-46 